Ковалева Н.Б.

\title{
ДЕЙСТВИТЕЛЬНОСТЬ ЮМОРА КАК СРЕДА И СРЕДСТВО РЕФЛЕКСИВНО-ПОЗИЦИОННОГО ПОНИМАНИЯ МИРА И СЕБЯ
}

\begin{abstract}
Аннотация. В статье исследуются проблемы понимания юмора в контексте практического решения задач разработки инновационных психолого-педагогических средств (моделей; технологий), имеющих своей целью развитие личности и ментальных способностей подростков и юношества. Юмор и комическое в аргументации автора представлены как дополняющее средство и среда самоосуществления человека, одно из условий обретения им внутренней свободы и целостного культурно-ориентирующего образа мира; совершенствования своей субъектно-творческой позиции. Образовательно-антропологический императив "во всем переустановиться заново» предписывает особое внимание к переменам в среде становления-возрастания молодежи, а динамичная современность медиакультуры и глобальное влияние массмедиа-одновременно являются вызовом и своеобразным педагогическим заданием. Ретроспектива теорий юмора, предлагаемого автором во временной рамке от античности до концепций медиакультуры и интерпретативных сообществ, - рассматривает юмор как средство построения диалогических отношений и особый способ присутствия в мире; как параллельную практику познания мира и себя. Обзор предшествующей традиции, выводящей к идее формирования творческой позиционности личности, позволяет органично включить в работу и подвести теоретический базис под авторскую рефлексивно-позиционную модель понимания юмора. По-новому раскрыть личностные механизмы становления и роста в пространстве медиакультуры, через творческое переоткрытие культурно-исторических ценностей для формирования проектно-мировоззренческих представлений о ценном, «должном и возвышенном». Автор на конкретных примерах иллюстрирует и показывает в выводах перспективы применения технологий рефлексивно-позиционного подхода к моделированию среды, инициирующей развитие способности понимания комического как фактора становления творческой позиционности личности.
\end{abstract}

Ключевые слова: комическое, юмор, ирония, рефлексия, “медиагерменевтика», диалог, творчество, позиционность, рефлексивно-позиционная модель, психология понимания.

Abstract. The article examines the problem of understanding of humor in terms of a practical solution to problems of development of innovative pedagogical tools (models or technologies) aimed at the development of personality and mental abilities of teenagers and young adults. The author considers culture and media reality of "the comic» as the medium of self-realization in the process of finding the inner freedom and integrity of the culture-orienating image of the world and development of creative thinking. Psychological-anthropological imperative "reinstall all attitudes from the beginning" requires special attention to changes in the environment of formation and growing in youth, thus a dynamic modernity of media culture and global influence of mass media are simultaneously a challenge and a kind of teaching job. The author's retrospective review of the theories of humor since ancient times and philosophy of the New Period till the modern concepts of social media, interpretive communities and media culture, regards humor as a way of presence in the world; as the practice and knowledge of the world itself as a construction tool of the dialogical relations. Such analysis allows to cover and prove the theoretical basis for the author's "reflexive-positional» model of understanding of humor and to reveal the mechanisms of formation of the creative personality in the process of rediscovering culture-congruent values and projective philosophical ideas about the "proper». By using specific examples, the author illustrates and shows prospects for using the reflexive-positional approach to modelling the environment initiating the concept of the comic as the factor of developing individual creative positionality.

Key words: positional feature, creativity, dialogue, media hermeneutics, reflection, irony, reflexive-positional model, humor, comic, psychology of understanding.

\section{Постановка проблемы}

Понимание комического и чувство юмора уникальная способность человека, претендующая на статус особого стиля и способа отражения и опи- сания мира в его проявлениях и интерпретациях, а также себя в качестве актора со-бытия в культурно-историческом контексте современной нам медиарельности. В глобальных трендах нового столетия понятия «образование через всю жизнь», 


\section{Внутренний мир человека}

«непрерывное образование», самообразование и многообразные «практики себя» постепенно обретают статус основного ресурса развития. Современность как эпоха «парадигмальных сдвигов и поворотов [6; 43]; неопределенности и текучести» [5]; «многомерности и нелинейности» [4]; «потоковых состояний сознания» [54]; «трансмедиа и интерпретативных сообществ» [12; 38] - создает необходимость переосмысления известной формулы личностного и образовательного самоопределения, понимаемого как императив: «во всем переустановиться заново» [45]. В качестве одного из механизмов ценностного самоопределения и развития творческих способностей человека, с точки зрения ряда ученых, можно рассматривать юмор и различные формы комического [13; 15;18; $19 ; 34$; $35 ; 42 ; 46 ; 47 ; 50 ; 60]$. Теории комического крайне многообразны и в большой степени противоречивы. Тем не менее, в основе большинства из них лежит понимание преобразующей силы комического и сопринадлежных ему смеха, юмора, иронии.

Автор диалогической концепции гуманитарного знания и мышления М. М. Бахтин в фундаментальном исследовании карнавальной культуры средневековья выделяет следующие характеристики смеха: «...смех имеет глубокое миросозерцательное значение, это одна из существеннейших форм правды о мире в его целом, об истории, о человеке; это особая универсальная точка зрения на мир; видящая мир по-иному, не менее (если не более) существенно, чем серьезность; поэтому смех так же допустим в большой литературе, как и серьезность; какие-то очень существенные стороны доступны только смеху» [7, с. 78]. Не менее важным представляется тезис о понимании смеха как механизма освобождения человека от страха, как источника свободы [7, с. 104]. По мысли М. М. Бахтина в средневековье и в эпоху Ренессанса именно смеховая культура, основанная на разных формах юмора и комического, создает условия для обретения человеком целостного правдивого образа мира, внутренней свободы и духовной автономии. Изменилась ли роль юмора, комического в современности? Каковы условия и возможности использования юмора для формирования целостного образа мира, построенного в соответствии с («правдой» о мире и) культуросообразным ценностями, в условиях усложняющейся и противоречивой медиасреды? Рассмотрим, приложив некоторое герменевтическое усилие, наиболее важные теоретические положения, позволяющие раскрыть природу юмора и комического, в попытке определить ресурсные возможности его понимания для разрешения проблем образовательных антропопрактик. Ответ представляется важным и необходимым в контексте задачи поиска технологических возможностей, средств личностного развития и творческого самоопределения человека в сложных условиях современного мира.

\section{Юмор и природа комического}

В энциклопедических словарях юмор определяется как особый вид комического, сочетающий насмешку и сочувствие, внешне комичную несерьёзную трактовку и внутреннюю причастность (и даже заинтересованность) к тому, что представляется смешным [57]. Подразумевается, что в отличие от разрушительного уязвляющего и обесценивающего смеха сатиры или пародии; саркастического смеха превосходства и доминирования, в юморе, а отчасти и в иронии под маской смешного скрыто отношение причастности и творческой заинтересованности в отношении предмета, в котором отмечена перспектива необычного, удивляющего, комического. Это обеспечивает более детальное отображение самого существа дела в рассматриваемом явлении, и через это же обретается некоторое необходимое дополнительное измерение в той оптике рассмотрения, на которую субъект претендует благодаря своему чувству юмора. Юмор является выразителем внутренней противоречивости явлений, соединяет в себе серьёзное и смешное, характеризуется преобладанием позитивного момента в исследовании новых сторон действительности, данной в юмористичеких описаниях или в рефлексивных самоописаниях акторов - субъектов самоиронии и юмора.

По мнению экспертов [31; 49; 50] комическое сложно определить в метафизических дефинициях в связи с его универсальностью (все на свете можно рассматривать «серьезно и комически»), а также в виду «протейности», коррелирующей с игровой способностью прятаться под любой личиной, чтобы быть пластичным, безликим или неуловимым как мифологический Протей. Обратимся к высказыванию Аристотеля о том, что сущностное и важное, подчас, прячется «под маской комического - безобразной, уродливой, но без страданий» [3, c. 30-35]. Интересную трактовку воззрений Аристотеля на природу комического дает А. Ф. Лосев. Восстанавливая весь доступный контекст высказываний античного Учителя по данной теме А. Ф. Лосев показывает, что Аристотель рассматривает комическое как эстетику выражения «значительного при помощи незначительного, когда от этого противоречия ни для кого не получается никакого страдания» [32, с. 527]. Последователь же Аристо- 


\section{Психология и психотехника 4(91) • 2016}

теля, излагая его учение (в Коаленовском трактате, который гипотетически может оказаться конспектом утерянной второй части «Поэтики»), пишет: «Комедия есть подражание действию смешному и неудачному совершенного размера, в каждой из своих частей в образах разыгрываемое, а не рассказываемое, через удовольствие и смех осуществляющее очищение подобных аффектов. Она имеет своей матерью смех». И добавляет, что хотя смех рождается из многого «что против ожидания», но только в настоящей комедии соблюдается «мера вещей» как «симметрия смеха» в отношении видимого и вероятного [32, с. 529], способствующая эстетическому переживанию.

Таким образом, в античности комическое характеризуется как противоречие между ожидаемым и реальным, происходящим из заблуждения ума, вызывающим в свою очередь естественный смех над комически маркированной ущербностью ложных надежд или иллюзорных ожиданий. При этом различается смех в рамках комедии, порождающий очищение, - от смеха низменного, грубого, не облагороженного мерой (вещей) и симметрией (действительного и комического), не могущего породить эстетическое переживание, а тем более катарсис. Также уже различается смехнасмешка (обесценивающая свой объект ирония); и смех - гротескный, уничижительный (сарказм, а в мягкой форме - пародия и сатира). И хотя они в дальнейшем находят свои легитимные классические литературные формы, но по факту они оказались противопоставлены смеху, облагороженному эстетикой меры: смеху - возвышающему и очищающему.

Так или иначе, но содержательным центром феномена комического оказывается неожиданный для зрителя разворот событий, иная экспозиция взора. Неожиданность разрешения инициирует «ага-эффект» и снятие напряженного ожидания в радостном жизнеутверждающем смехе. И. Кант в «Критике чистого разума» снабжает эту мысль яркой метафорой: «Смех является эмоцией, возникающей из неожиданного превращения напряжённого ожидания «в ничто» (так как при произнесении ключевого слова, «соли анекдота», наше предчувствие об ожидаемом продолжении не исполняется)».

С точки зрения психологии можно сделать вывод о том, что комическое и вызванные им чувства возникают там, где происходит неожиданное переворачивание взгляда на предмет или событие. Кантовское положение допускает представление о прерывности сознания: в комическом внезапный разрыв останавливает движение сознания (в данном случае - игру представлений) на границе с ничто [22, с. 361]. Толкование И. Кантом комического контраста или противоречия послужило исходным пунктом для разработки теории комического Ф. Гегелем. Рассматривая природу комического как эстетической категории, философ обращается к ситуациям, когда человек утверждает себя в своей субъективности и не стремится к познанию Всеобщего. Ф. Гегель показывает, что комическим является «субъективность, которая через саму себя приводит свои действия к противоречию и разрушает их, но при этом остается вместе с тем спокойной и уверенной в себе». То есть юмор как нарративное событие возникает там, где радостная уверенность индивида в серьезности и значимости своих целей, порожденных «субъективностью», вступает в противоречие с их ничтожностью или ложностью в масштабе объективности и истинности Всеобщего. Такие цели и ценности легко «гибнут, так как лишены субстанции», в то время как субъект остается невредимым [17, с. 72]. Теоретические воззрения Ф. Гегеля создают возможность рассмотрения настоящих комедий (таких как у Аристофана или Шекспира) в психолого-педагогическом ракурсе: так как раскрытие реальной ограниченности субъективной самоуверенности человека в своей правоте, по сути есть условие и возможность для переосмысления субъектом оснований собственной жизни и понимания тщетности многих своих усилий на ложно выбранном пути.

Более полное психологическое насыщение эти мысли находят в трудах Жан-Поля. В трактате «Приготовительная школа эстетики», продолжая мысль Ф. Гегеля, он противополагает «смешное возвышенному» также, как «малое - бесконечновеликому». Жан-Поль последовательно переориентирует внимание исследователя с комедийного действия, разворачивающегося на сцене, на процессы, которые происходят в самосознании зрителя или читателя. С точки зрения Жан-Поля смех и юмористический настрой возникают в контексте «одновременного наслаждения тремя мыслительными процессами, предстающими и утверждаемыми в едином созерцании». Это, во-первых, наши собственные естественные мысли; во-вторых, реальные мысли другого человека, находящегося в той же ситуации; и в третьих, - «приходящие из вне иллюзорные мысли, которые начинают себе подчинять и волю и чувства» [20, с. 134]. Комический контраст становится фактором (драйвером), провоцирующим работу сознания, в котором происходит процесс «сопряжения» собственных представлений смеющегося субъекта с действиями и 


\section{Внутренний мир человека}

устремления смешного персонажа, которые в психологических терминах можно проинтерпретировать (представить) как процессы эмоционального сопереживания героям; в опоре на интенцию понимания «иллюзорности малого» и рефлексивнопроектной «устремленности к большому, великому, истинному».

Теоретические концепции российских ученых развиваются в широком диапазоне направлений: в частности, это концепции эстетического Ю. Б. Борева [13]; этнографические и историко-культурные исследования М. М. Бахтина [7], Д. С. Лихачева, А. М. Панченко, Н. А. Понырко [31], В. Я. Проппа [40]; психологические работы о юморе В. В. Лука и других ученых [33; 35; 39]. Значительная часть российских ученых, несмотря на разность подходов и научных платформ, также сходится во мнении, что природа юмора и комического соотнесена с в первую очередь с ценностно-смысловой сферой мышления и самосознания. Так, Ю. Б. Борев $[13$, с. 170$]$ определяет комическое как «явление, представляющее реальность в неожиданном свете, вскрывающем ее внутренние противоречия и вызывающем в сознании воспринимающего активное самостоятельное противопоставление предмета эстетическим идеалам». Сходную точку зрения разделяют другие современные исследователи, рассматривая комическое, например, как одно из «средств духовного оружия людей против любого вида зла» $[47$, с. 132$]$.

\section{Психологические теории юмора}

С уважением относясь к озабоченности С. А. Троицкого, настаивающего на необходимости гносеологического различения смеха, юмора, комического в связи с тем, что: «проблемное поле юмор» несводимо к содержательной рамке понятия и явления «смех» $[49$, с. 313], - мы всё же будем придерживаться теоретических интенций А. В. Дмитриева и А. А. Сычева. А именно: «Понятия «юмор», «смех» с течением времени переливаются из одного смыслового русла в другое, самым парадоксальным образом меняя значения и ассоциации с ними связанные. Различить оттенки и подтексты в значениях этих понятий представляется реальным только в момент самого перехода, в котором понимание приобретает толчок к саморазвитию» [цит. по 49, С. 313].

Психологи выделяют различные функции юмора с точки зрения личностного развития. В контексте культурно-исторической психологии [16] это, в частности, развитие метапредметных способностей и личностных качеств, формируе- мых на основе знакомства с юмористическими произведениями известных авторов в той или иной образовательной среде: развитие рефлексии, эмпатии, гибкости; актуализация творческой внутренней свободы личности [24; 33; 39]. Ряд современных авторов подчеркивают, что юмор это одна из «познавательных структур», которая позволяет выявить противоположные свойства объекта или его описания, а одновременно вместе с тем, - позволяет утвердить норму объекта через обратную позицию [15]. Можно предположить, что нормой здесь является то личное, но объективно достоверное знание, которому мы приписываем свойства ориентировать, прогнозировать последствия, руководить нами в действии, событии, деятельности - в жизни в целом, а особенно в проблемных ситуациях недоумения, растерянности, фрустрации, дефицита компетенций и информированности. Норма, таким образом, может быть понята здесь как желательное практически применимое и ранее апробированное знание.Иной пласт способностей связан с коммуникативной природой юмора, на что указывал в своей работе А. Бергсон: «Чтобы понять смех, надо рассматривать его в его естественной среде, которая есть общество» $[9$, с. 499]. Неким важным комментарием, различающим «юмор» и «иронию», оказывается замечание В.В. Янкелевича: «Ирония, по Бергсону, провозглашает видимое, делая вид, что принимает его за реальное, в то время как юмор описывает реальное, делая вид, что принимает его за идеальное. Отсюда невозмутимая аналитическая тщательность и мелочность юмора, противоположная красноречию иронии» [58, С. 131].

Значимый фокус рассмотрения юмора и комического как регулятивной функции общественного сознания появляется в контексте работ создателя теории коммуникативного действия и дискурсивной этики Ю. Хабермаса [53]. Психологически перспективным тезисом его теории «коммуникативного разума» [56] оказывается то, что «истина и благо», «устанавливаемые на основе лучшего аргумента», по мнению людей призванных к диалогу и согласию, - совпадают. В этом случае (при соответствующем психолого-методическом обеспечении) юмор и ирония становятся средством разрешения межличностных и межгрупповых конфликтов и начинают выступать в качестве особой, превентивной меры предотвращения эскалации накапливаемых напряжений и конфликтов (как в дискуссиях о «лучшем аргументе», так и непосредственно в самой жизни общества).

Коммуникативная природа смеха убедительно раскрывается в диссертации А. А. Сычева: «При- 


\section{Психология и психотехника 4(91) • 2016}

роду смеха невозможно свести к бытию субъекта или объекта, она проявляется только в сфере их взаимодействия. Онтологическая основа смеха общение, диалог двух субъектов, совместная коммуникация людей, социальных групп, культур: смех укоренен на коммуникативном уровне общественного бытия. Смеховая коммуникация ... отличается неполнотой и незавершенностью даже в диалоге двух субъектов. Смех изначально требует социального пространства, поскольку осуществление функций смеховой культуры направлено на поддержание целостности социальной системы и процессов самоорганизации культуры» [47, с. 23]. В данной работе поднимается важный вопрос о роли юмора и смеха в процессах формирования общественного сознания и самосознания отдельных индивидов; в поддержании системы общественных связей и отношений.

Для нашего исследования представления о диалогической природе смеховой коммуникации, равно как и аспекты рассмотрения роли юмора в культурном опосредовании складывающихся групповых (общностных) взаимоотношений имеют особую значимость. А. А. Сычев, продолжая мысль М. М. Бахтина о роли смеха в оздоровлении и уравновешивании противоречивых тенденций общественного развития, затрагивает еще два важных аспекта. 1. Влияние юмора на формирование общности. Известно, что специфический язык шуток возникает в различных субкультурах и знание их является своеобразным пропуском в них, и в какой-то мере этот же механизм «работает»в соцсетях. 2. Роль юмора в самоопределении людей в системе общественных ценностей. Смех и юмор могут быть направлены как на поддержание легитимности существующих ценностных ориентиров, так и на их дискредитацию. Вопрос о психологических механизмах самой возможности такого влияния остается открытым.

Интересную версию смысловой концепции представляет в своих работах Л. В. Карасев. В ее основании гипотеза о смехе как о символическом целом, развивающемся по своим внутренним законам [23]. По мнению ученого, история изучения феномена смеха проходит под знаком эстетической трактовки смеха, данной Аристотелем. С психологической точки зрения представляется важным, что в качестве основных механизмов в данной концепции выделяются эмоции и рефлексия [23].

Рассмотрим некоторые принципы построения юмористического высказывания на примере. В новелле «Совет Шоу» Бернарда Шоу «Одна назойливая дама спросила у Бернарда Шоу, как лучше писать, чтобы стать знаменитым писателем». Шоу ответил: «Слева направо». За вопросом дамы о секретном рецепте популярности стоит известная логика, подсказывающая: «Писать книги - важное занятие, именно ему следует придавать значение. А в том, как они написаны, и скрыт весь секрет как стать популярным». Вольно или невольно читатель принимает эту логику и ждет не менее серьезного ответа. Б. Шоу отвечает на это: «Слева направо», - и вводит в ситуацию пресловутый элемент неожиданности. Топографический ответ Б. Шоу «слева направо» проводит черту между созданием книги и процессом письма. Действительно, мы пишем по правилу «слева направо», не имеющему никакого отношения к творческому событию создания книги, истории, личного высказывания, - как известного способа самообнаружения себя, занятого поисками значимого Другого. Ответ высвобождает то внимание, с которым мы были готовы внимать заведомо скучным рассуждениям о «природе таланта». Именно потому, что мы сами подсознательно тяготимся этим вопросом, наше напряженное ожидание ответа оборачивается эврика-эффектом, смехом и в некотором смысле микрокатарсисом: серьезность вопроса дамы нивелируется в этот момент, а существо дела обретает свою подлинную серьезность: суть и смысл. По словам В. В. Янкелевича: «Между всеми возможностями, которые предоставляет разум, ирония выбирает самое наибольшее «другое»» [58, С. 51].

Рефлексивно-позиционный подход к пониманию юмора как средства обретения свободы мышления для переосмысления картины мира

С точки зрения рефлексивной теории творческого мышления $[1 ; 21 ; 27 ; 44]$ человек обретает свободу тогда, когда преодолевает стереотипное видение или понимание предмета. Эта закономерность выводится Н. Г. Алексеевым [1] на основе анализа размышлений о рефлексии в трудах И. Фихте, и может быть проиллюстрирована следующей схемой (рис.1).

Мы видим, что рефлексия понимается здесь как акт творческого переосмысления изначальных, стереотипных представлений о предмете. Сам И. Фихте рассматривает рефлексию как возможность встать над «предрассудками» и сделать шаг к объективированному представлению и, тем самым, осуществить свою свободу в знании (свобода бытия, с точки зрения философа, требует гораздо более серьезного личностного усилия) [52, с. 404410]. Н. Г. Алексеев, продолжая размышления философа, показывает, что рефлексия действительно направлена на преобразование, изменение представлений человека о мире и о себе в нем, то есть имеет творческую природу. Более того, он пред- 


\section{Внутренний мир человека}

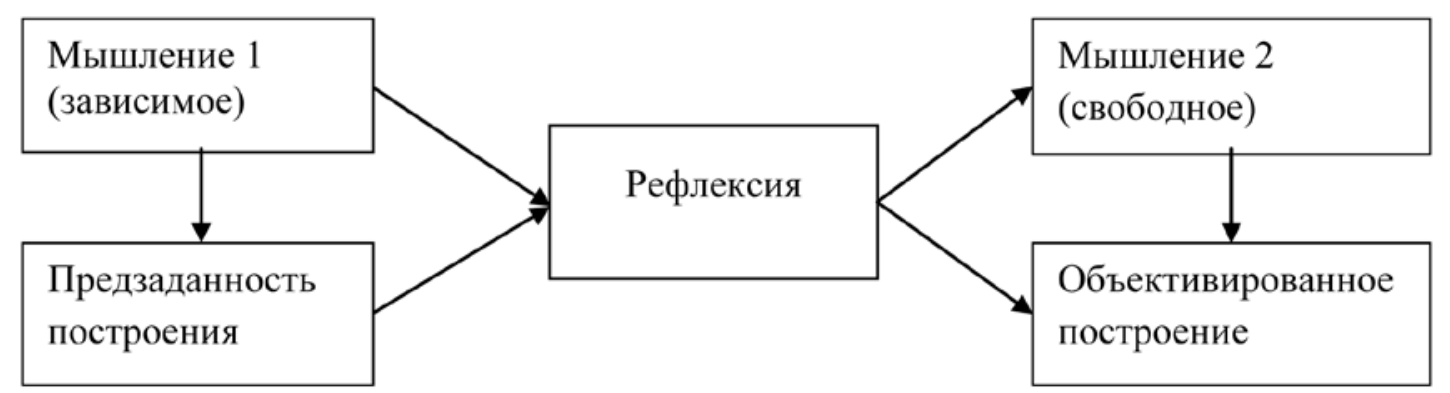

Рис. 1. Обретение свободы мышления в рефлексивном акте

лагает систему рефлексивных действий по «вытаскиванию себя за волосы из болота субъективных мнений», ставшую классической, не потеряв при этом свой актуальный конструктивный потенциал [1]. В предлагаемой системе всего 4 действия: остановка, фиксация, отстранение и объективация (два последних действия могут меняться местами). В этой концепции обретение свободы мышления осуществляется (в случае возникшего затруднения или обнаружения проблемы) на основе остановки действия, фиксации затруднения, ревизии и преодоления некритично усвоенного суждения, поверхностного взгляда; построения нового, соотнесенного с культурным значением, понимания ситуации; наконец, личностного осмысления (оборачивания на себя) полученных знаний. Применение данной системы к анализу разбираемого юмористического высказывания Бернарда Шоу, позволяет предложить следующую схему сборки: а) остановка инерционного восприятия по стереотипам и клише, вмененного понимания, предрассудочного видения; б) фиксация противоречия в понимании, возникшего за счет юмористического высказывания; в) отстранение и юмористический взгляд на свои прежние упраздняемые, снимаемые и преобразуемые представления; в) обнаружение культурного значения ситуации; г) переосмысление собственной ситуации (оборачивание нового взгляда на себя), рефлексивное схватывание нового качества видения себя с осознанием преобразования собственной субъектной позиции.

Такова последовательность стадий (этапов) самоизменения в аспекте мыслительных процедур и действий, необходимых для получения нового продуктивного знания в ситуации понимания юмора в рефлексивной теории творческого мышления (рис. 2).

С точки зрения рефлексивно-позиционного подхода [25-29; 36; 59], способность понимания юмористического текста в значительной мере определяется развитием рефлексивного мышления и коммуникативных способностей. К комму- никативным способностям относятся способности понимания и репрезентации позиции и средства их согласования в диалогическом событии. Юмор и ирония понимаются нами как формы комического, основанные на мыслительной способности вскрытия противоречий и деконструкции (выявления детерминант и логик в отношении) их оснований. Противоречия преодолеваются в оптике парадоксальной точки зрения, за счет внесения нового неожиданного фактора в контекстуальное поле. Противоположности «снимаются» по-разному: за счет усмотрения большого в малом; за счет пересмотра значимости прежних целей и ценностей; за счет переосмысления и гармонизации ситуации в контексте эстетического переживания.

В анекдоте, как правило, противоречие разрешается радикальным расширением контекста возможных толкований или в очередном «абсурде», что и является причиной смеха. В «новом абсурде» возникает новая ясность: позиция, позволяющая видеть абсурд, должна сама по себе иметь достаточно большую жесткость и основательность, быть непричастной ситуативным рамкам, являясь позицией «над» или «вне».

Ироническая позиция - «позиция над» с уклонением от предпочтений любой из изначально привлекательных альтернатив. Если в абсурдной форме показывается мелочность «спорящих до посинения» героев (акторов ситуации, события), то смеющийся над ними выделяет как важное свою возможность встать выше спора и вне его. Косвенно этим постулируется, что ценности лежат вне функционально закрепленных форм, надетых на героев как карнавальный балахон или униформа, согласно их ролевой идентификации.

Соответственно, понимание юмора возможно только в соотнесении с системой ценностей, вне которой все эти переходы оказываются бессмысленными. Юмор борется с незыблемостью идеалов и мифов, с догматической предзаданностью истин и «правильных» мнений, с вмененным пониманием и с принуждением. Интересно, что данная кон- 


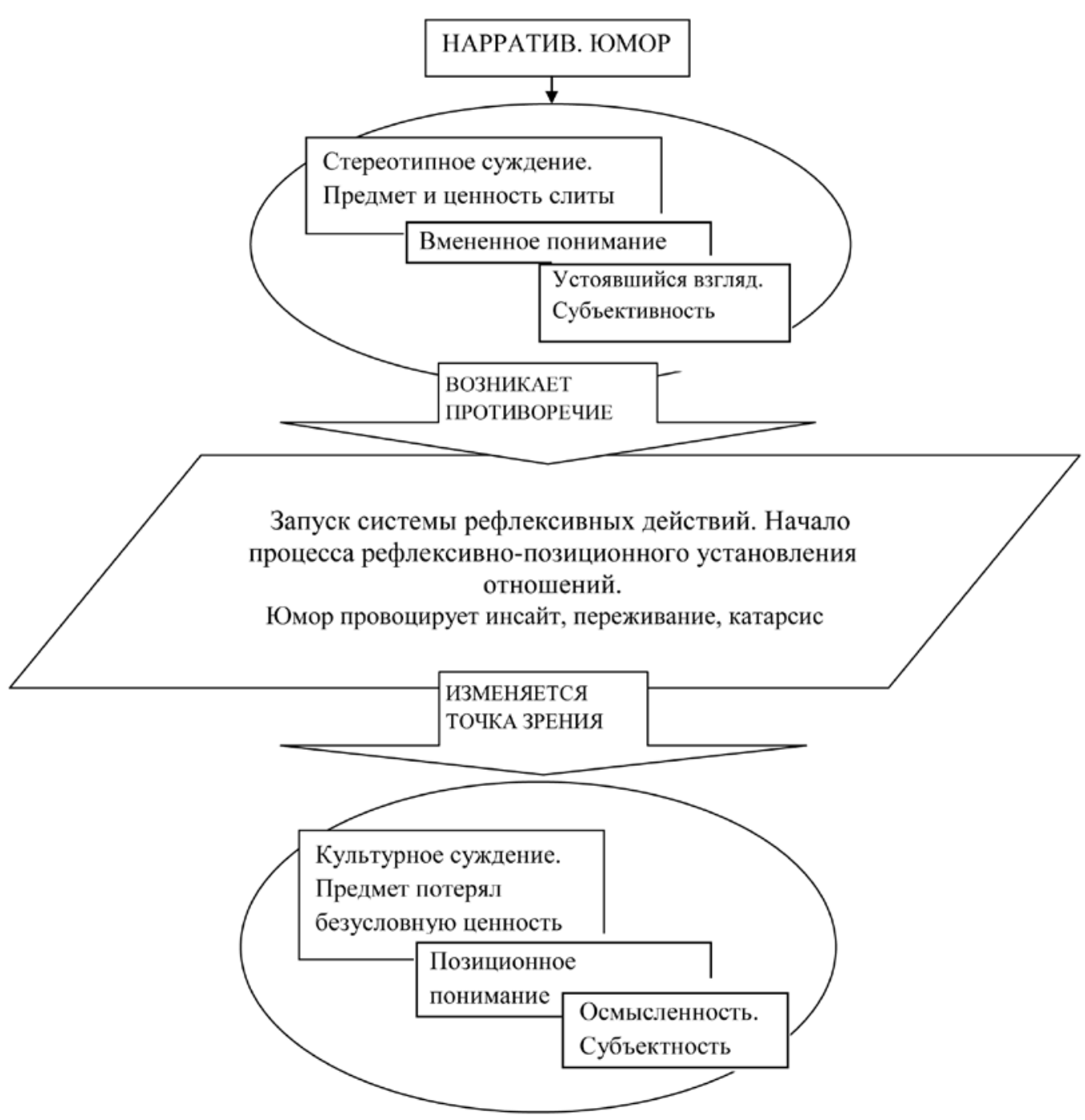

Рис. 2. Рефлексивно-позиционная схема понимания юмора

цепция юмора хорошо сопрягается с теоретическим воззрением других авторов [10; 33-37; 46, 50]. В частности А.Н.Лук [32], выделяет следующие предпосылки для понимания юмора:

- способность к отчуждению, умению видеть себя как бы сторонним взглядом;

- способность видеть вещи под неожиданным углом зрения;

- «раскованность» мышления, лёгкость ассоциирования, отсутствие страха.

Первые две предпосылки, очевидно, связаны с рефлексией в принятом нами понимании. Как было показано в наших работах, в концепции Н. Г. Алексеева отстранение (эмоциональное снятие значимости наличной актуальной позиции) является одним из основных рефлексивных действий, наряду с остановкой действия, фиксацией, объективацией и оборачиванием. Умение видеть себя со стороны, а вещи под неожиданным углом зрения это результаты рефлексивных действий, обеспечивающих творческую позицию человека. Объективация результатов интуитивных прозрений обеспечивается такими мотивационно-личностными факторами как свобода мышления, чуткость к латентным смыслам, полипозиционность мышления, отсутствие установок на самоограничение, инициативность [27].

Таким образом, рефлексивно-позиционный метод анализа текста или высказывания позволяет выделить следующие функционально рефлексивные действия по его пониманию:

1. Реконструкция предмета и содержания самого текста; позиции его автора.

2. Позиционно-ролевой анализ текста. Выявление всех функционально-ролевых позиций и их определение. 


\section{Внутренний мир человека}

3. Установление отношений между функционально-ролевыми позициями всех субъектов (автора, героев, читателя, критика, т.п.), включенных в ситуацию: а) гипотетической позиции автора новеллы; б) своей предварительной точки зрения; в) позиции любопытствующей дамы; г) позиционные следы актора-писателя, он же персонаж авторского повествования.

4. Первичная выработка позиционного отношения и построение позиционного высказывания на основе встречного понимания.

Комизм - в несовместимости «реальности» спрашивающего и «действительности» отвечающего; их разнокачественности и разномасштабности; их внеположенности по отношению к другдругу - как миры они взаимоперпендикулярны! Но при серьезном подходе к сравнительному анализу присущих той или иной позиции ценностей, компульсивное (вне рациональных оснований) опровержение значимости одной из них - усиливает значимость и влияние как раз опровергаемой позиции, её достоинства, косвенно подтверждаемого мощью и изощрённостью красноречия критикующего оппонента. Как мы видим, при юмористическом взгляде и ироническом способе отношения, при не пропорциоанальном ценности объекта атаки низпровергающем усилии, выказанном по ходу дискуссии, - необходимо укрепляется другая (собственно говоря, критикуемая) позиция, как будто одалживая часть энергии и сил у своего интенсивного «не по разуму» визави.

Медиагерменевтическое усилие в декодировании опосредующих описаний помогает нам через смену позиций выявить новый ракурс рассмотрения, в котором знакомая вещь иначе интерпретирует себя, предъявляя новый абрис своей формы [26; 29; 59]. В этой новой экспозиции - знакомое, подчас, приобретает качества не знакомого и не ожиданного. Это можно уподобить своеобразной переустановке света на сцене пещеры Платона, новое измерение или проекция видения, - и новые мы, по-новому, из другого пространства возможностей, взирающие на привычное для нас содержание.

Юмор и ирония, таким образом, опираются на специфически культурные способности художественно и критически вскрыть несоответствие описания и факта, или зафиксировать противоречие между видимым и скрытым. В этом смысле юмор выступает как мыслительные средства осуществления ревизии оснований, предмета, содержания наших предрассудков или некритично усвоенных мнений; декодирования симулякров; прояснения природы базовых представлений, ориентирующих нас в отношении нашего прошлого, настоящего и будущего. Рефлексивно-эвристическая функция комического (юмора, иронии, сатиры, сарказма) превращается тем самым в инструмент проблематизации и переосмысления существующего положения вещей как в приватной области самопознания-познания, так и в области публичных гуманитарных практик, а в конечном итоге становится источником различных личностных новообразований: ценностной основы самосознания, мировоззренческих идеалов, картины мира, духовно-нравственных убеждений, социокультурной идентичности.

Проблемы и возможности развития ценности юмора и способности понимания комического в подростковой и молодежной среде

Развитие культуры понимания юмора и комического имеет особое значение для молодежной аудитории. Проблема формирования культуры понимания текстов (в живом и опосредованном общении в детской и юношеской среде) сама по себе, несмотря на фиксируемый герменевтический бум, до сих пор в достаточной мере не нашла своего разрешения в социокультурной практике воспитания, образования и управления образованием $[11 ; 14$; $28 ; 30 ; 34 ; 41 ; 55]$.

Хотя и существует немало интересных прецедентов формирования культуры понимания текстов, в том числе юмористических, на различных ступенях основного и дополнительного образования [29; 37;46; 48], - общий уровень культуры понимания текста, по признанию ведущих экспертов, стремительно падает. Феномены «вмененного понимания», клипового мышления, фоновая ротация миметического ширпотреба, получающие все большее распространение $[2 ; 26,28,36$, 59], яркое подтверждение этому. Подтверждают такую ситуацию, в частности, и наши собственные исследования.

В течение нескольких лет нами проводились исследования современных представлений старшеклассников и студентов по теме «Образ образованного человека» [25-28]. В общей сложности проведена экспертиза порядка 1000 творческих работ. Анализ данных эссе и других творческих работ позволяет зафиксировать, что чувство юмора упоминается как качество, необходимое образованному человеку, крайне редко и не имеет статистически значимых показателей. В представлении молодежной аудитории юмор не имеет самостоятельного статуса в качестве образовательной ценности или общей характеристики образованности. Среди студентов факультета начального 


\section{Психология и психотехника 4(91) • 2016}

образования МПГУ на прямой вопрос, нужно ли чувство юмора учителю, большая часть студентов ответила, что нужно, но как дополнительное, не основное качество. Модель педагогического профессионализма для многих из них пока строится на представлениях о педагоге, как о человеке, транслирующем информацию в виде «готового знания», и не практикующего в качестве средства и условия совместного с учениками открытия и освоения ими знаний - исследовательский диалог, в пространстве которого чувство юмора оказывается более чем востребовано. Ниже приведены некоторые результаты комплексного исследования способностей понимания текста студентами 2 курса МПГУ факультета начального образования, проведенного на материале фильма Марка Захарова «Тот самый Мюнхгаузен».

Основная цель: определение характеристик понимания разного рода медиатекстов (пословицы, метафоры, картинки, стихи, мультимедиа объекты, прочее) через соотнесение с картиной мира и ценностными ориентациями самих студентов.

Один из субтестов был направлен на диагностику способности понимания юмора (на материале высказывания из фильма «Тот самый Мюнхгаузен», ставшего крылатым выражением: «Присоединяйтесь, Господа, присоединяйтесь». В фильме с призывом «Присоединяйтесь, Барон. Незаметно присоединяйтесь!» попеременно к барону обращаются: его официальная супруга; бургомистр; король. Часть результатов представлена в табл. 1.

Обобщенные результаты свидетельствуют о том, что культурное значение фразы «Присоединяйтесь, господа, присоединяйтесь!» с годами изменилось: яркая когда-то форма прижилась в языковом обиходе, но её ирония и сарказм оказались элиминированы в пользу прямого значения: «ловкое и изящное приглашение в компанию» (чаще всего для развлечения) - очередной нарратив языковой игры! Даже большая часть из тех, кто смотрели фильм, тем не менее, не реконструировали контекст фильма, оставшись в привычном «идиоматическом» понимании смысла этого обращения (70\% опрошенных). Еще 30\% воспроизвели контекст формально, раскрыв значение фразы через отрицательную коннотацию: как приглашение присоединиться к «нехорошему обществу или сомнительному делу».

Ответы совершенно другого качества и уровня получены в формирующем эксперименте от студентов, предварительно участвовавших в сюжетно-деятельностном медиагерменевтическом тренинге, построенном на технологиях рефлек- сивно-позиционного подхода к сценированию ситуаций «развития метапредметных способностей и личности учащихся в пространстве диалога и совместного творчества» [27; 28].

Первый тип ответов, «эмпативно-рефлексивный», возникает на основе сопереживания герою в затруднении, через осознание сложности его выбора. Второй тип ответов эксплицирует понимание ценностной или мировоззренческой основы высказывания, выраженной одной из студенток следующим тезисом: «Они - безликая масса и потому нетерпимы к неординарности. Их задача приобщить, превратить и Барона - в массу, лишив его индивидуальности. Это предложение Барону, во избежание неприятностей, - «стать как все»». По признакам определения типа комического высказывания это уже не юмор, а сарказм, направленный на осмеяние лицемерия общества «массы», претендующего на привлекательность своего, якобы, «исключительно ценного» статуса. Третий тип ответов демонстрирует творческое личностно-осмысленное понимание ситуации. Более 50\% студентов данной группы привлекают образный метафорический язык и формулируют парадоксы: «быть в согласии со всеми, но только не с собой»; «не жить, а играть роль»; «переступить через себя»; «уйти на чужую территорию и начать петь чужие песни»; «стать серийно-выпускаемым калиброванным изделием с порядковым номером».

Обращает на себя внимание тот факт, что в процессе творческого обсуждения фильма (на рефлексивном такте проектного сценария) многие студентки отметили, что наибольшую сложность в понимании и интерпретации вызывает именно эта фраза. Причина этого, думается, кроется в парадоксальной и многомерной природе комического, а в отдельных случаях, - и в его неочевидности. Требующей, в свою очередь, настойчивого медиагерменевтического усилия для преодоления стереотипного хода мысли; переосмысления и собственной картины мира. И для понимания стремлений, надежд и мотивации собеседников; всех возможных акторов события диалогической коммуникации.

Эти мыслительные способности, равно как и соответствующие им компетентности или образовательные результаты, стихийно не формируются в среде компьютерных игр; компульсивного времяпрепровождения в социальных медиа и сёрфинга по ссылкам. Но требуют для своего формирования и реализации проектирования и разработки специальной среды, образовательных моделей и психолого-педагогических технологий. 
Результаты исследования понимания юмора в формирующем эксперименте

\begin{tabular}{|c|c|c|c|}
\hline Серии & \multicolumn{2}{|c|}{$\begin{array}{c}\text { Результаты серии } \\
\text { констатирующего } \\
\text { эксперимента }\end{array}$} & $\begin{array}{l}\text { Результаты серии } \\
\text { формирующего } \\
\text { эксперимента }\end{array}$ \\
\hline \multirow[t]{2}{*}{ Тип ответов } & $\begin{array}{c}\text { Не смотрели } \\
\text { фильм / } \\
20 \text { чел. } \\
\end{array}$ & $\begin{array}{l}\text { Смотрели } \\
\text { фильм / } \\
10 \text { чел. }\end{array}$ & $\begin{array}{c}\text { Размышляли } \\
\text { над фильмом в технологиях } \\
\text { медиагерменевтики / } 26 \text { чел. }\end{array}$ \\
\hline & \multicolumn{3}{|c|}{ В \% \% от общей численности данной группы } \\
\hline $\begin{array}{l}\text { Формально-логический. Поверхностный, неверный. Противоречие не вы- } \\
\text { делено. Ценность однозначно положительная или нейтральная: приглаше- } \\
\text { ние в общество, в компанию. Рефлексия отсутствует. }\end{array}$ & 100 & 70 & 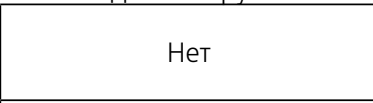 \\
\hline $\begin{array}{l}\text { Конкретно-ситуативный. Контекстно-формальный. Противоречие выде- } \\
\text { лено: противостояние героя и общества. Ценность однозначно негативная: } \\
\text { приглашение в общество лжи. Предметно-операциональная рефлексия. }\end{array}$ & Нет & 30 & Нет \\
\hline $\begin{array}{l}\text { Контекстный-ситуативный. Личностно-значимый. Эмпативно-рефлек- } \\
\text { сивный, предметный. Противоречие раскрыто как конфликт ценностей в } \\
\text { ситуации выбора и борьбы. Ценность самоопределения. Выбор между: } \\
\text { «быть принятым» и «быть не как все». Переживание ситуации выбора как } \\
\text { актуальной. Эмпативно-предметная рефлексия ситуации. }\end{array}$ & Нет & Нет & 15 \\
\hline $\begin{array}{l}\text { Культурно-опосредованный. Объективированный, отстраненный. Проти- } \\
\text { воречие осмысляется в культурном контексте как позиционное, но не имеет } \\
\text { признаков личностного осмысления: индивид и общество; индивидуаль- } \\
\text { ность и масса; стереотип или норма творчества. Ценность: сохранение } \\
\text { индивидуальности, жизнь в обществе. }\end{array}$ & Нет & Нет & 31 \\
\hline $\begin{array}{l}\text { Творческое, личностно-осмысленное. Понимание парадоксальности } \\
\text { развития, появление собственных формулировок и метафор. Ценности: } \\
\text { личностного развития, позиционности, способности аргументировано } \\
\text { отстаивать свою позицию и независимо прокладывать свой путь, иметь } \\
\text { собственную точку зрения. }\end{array}$ & Нет & Нет & 54 \\
\hline
\end{tabular}

Апробированными и достаточно эффективными являются технологии сюжетно-деятельностных игр (СДИ) и медиагерменевтики, построенные на принципах рефлексивно-позиционного подхода [26-28; 59]. Данный подход и разработки на его основе позволяют моделировать процессы творческого самоопределения и личностного выбора в опоре на систему медиатекстов и аудиовизуальных образно-метафорических культурных образцов. Применение этого технологического комплекса позволило, в частности, преодолеть проблемы понимания разбираемого образца за счет:

a) создания условий для формирования творческого коллектива, общности, объединенной как ценностями развития, так и поисками общей сплачивающей цели или дела;

б) осознания значимости способности понимания медиатекстов в рефлексивно-позиционной диалогической коммуникации в процессе личностного самопреобразования-становления;

г) формирования «работающих» условий для совместного творчества; и в том числе - условий для развития способности понимания юмора;

в) открытия творческой многомерности образа и личности Барона, проявляемых во всей парадоксальности его поступков и в выборе нетривиального способа присутствия в мире.

\section{Выводы}

Подводя итоги, можно сделать следующие выводы:

1. Культура понимания комического и юмора в большой мере обеспечивается развитыми формами рефлексии, но не сводится только к ним, так как в этом смысле рефлексия инструментальна и орудийна, является подчиненным средством ценностного самоопределения и свободного творческого размышления. Важное значение здесь имеют также такие мотивационно-личностные факторы как гибкость в изменении точки зрения в рамках необходимого и достаточного культурного кругозора; социальная смелость и независимость; волевая интенция к преодолению ограничений в собственном развитии путем осознанных самоизменений; творческая интуиция; чувство «хорошей формы»; метафоричность и парадоксальность мышления.

2. Критериями понимания комического являются:

2.1. Общие критерии понимания авторского текста или высказывания - выделение и фиксация предмета комического, восстановление контекста; диалогическая коммуникация; позиционная рефлексия; образность языка.

2.2. Дополнительные критерии, специфические для понимания юмора: 


\section{Психология и психотехника 4(91) • 2016}

- Выделение «значимого» предметно-содержательного аспекта (свойства, предрассудка, суждения, идеи), над которым иронизирует автор; и фиксация изменения его статуса на «незначимый»;

- Выделение противоречия (конфликта), лежащего в основании смешного; поиск способа снятия или трансформации этого противоречия (конфликта) через порождение нового взгляда на ситуацию с иной точки зрения;

- Различение своей и авторской точки зрения на предмет. Наличие позиционного отношения (в форме суждения, иронии, метафоры, аргументированного неодобрения и т.п.) к заданному тексту или его интерпретациям;

- Знание критериев и специфики порождения комической или юмористической формы высказывания (суждения); и способность осознанно и целесообразно применять их в собственной практике.

3. При совместном решении задач на понимание комического успешность работы определяется не только рефлексивной культурой и творческими задатками каждого, но и избранными способами функционально-ролевой соорганизации всей группы.
Не менее важны ценностно-смысловая и целевая направленность группы как макросубъекта коллективной деятельности:

a) на успех в этой образовательной сессии, посвященной проблеме понимания юмора и иронии в качестве стиля и способа построения отношений с реальностью и со своим окружением;

б) на творческий результат, достигаемый в виде новой оспособленности мыслительными средствами, а также способами групповой соорганизации;

в) на общие проектные цели, общее понимание продуктивности применяемых отдельных мыслительных техник; и технологий соорганизации групповой проектной работы;

г) на расширение своего культурного кругозора и установление контактов со своими (потенциально) единомышленниками с целью сотрудничества в будущем.

Юмор в таком контексте является камертоном доверия и доверительности в складывающихся отношениях внутри группы, признаком высокого качества внутригрупповых отношений и рефлексивно-позиционной культуры участников.

\section{Список литературы:}

1. Алексеев Н. Г. Проектирование и рефлексивное мышление // Развитие личности. 2002. № 1. С. 92-115.

2. Акчурина Н. Н., Дьяконова А. И., и др. Практикум по преобразованию ФГОС в образовательные программы начального, основного и полного общего образования. М.: ГАОУ МИОО, 2015. 348 с.

3. Аристотель. Об искусстве поэзии. М., 1983. 184 с.

4. Асмолов А. Г. Вызовы современности и перспективы профессионального роста в мире образования // Образовательная панорама. 2016. № 1 (5). С. 6-8.

5. Бауман 3. Индивидуализированное общество. М.: Логос. 2005.90 с.

6. Барт Р. Избранные работы: Семиотика. М.: Прогресс, 1989. С. 415-418.

7. Бахтин М. М. Творчество Франсуа Рабле и народная культура Средневековья и Ренессанса. М.: Худож. лит,1990. 543 с

8. Бахтин М. М. Эстетика словесного творчества. М.: Искусство, 1979.543 с.

9. Бергсон А. Смех. Пер. с фр. М.: Панорама, 2000. 606. с.

10. Берн Э. Игры, в которые играют люди. Люди, которые играют в игры. М.: Эксмо, 2010. 560с.

11. Богин Г. И. Обретение способности понимать: введение в герменевтику. Тверь, 2001. 516 с.

12. Бодрийяр Ж. Симулякры и симуляция. Тула: Тульский полиграфист, 2013. 204 с.

13. Борев Ю. Б. Комическое и о том, как смех казнит несовершенство мира, очищает и обновляет человека и утверждает радость бытия. М. ; Искусство, 1970. 275 с.

14. Булин-Соколова Е. И., Обухов А. С., Семенов А. Л. Будущее педагогическое образование. Направление движения и первые практические шаги // Психологическая наука и образование. 2014. Т. 19. № 3. С 207-226.

15. Веракса Н. Е., Дьяченко О. М. Элементы карнавальной культуры в развитии ребенка-дошкольника//Вопросы психологии. М., 1994, No2. С. 77-87.

16. Выготский Л. С. Проблема культурного развития ребенка. // Вестн. МГУ. Сер. 14. Психология. 1991. № 4. С. 5-19.

17. Гегель. Соч. : в 14 т. : Т. 12: Лекции по эстетике, Кн. 1 М., 1938. 494 с.

18. Дземидок Б.. О комическом (пер. с польского). М.: Прогресс, 1974. 223 с.

19. Дмитриев. А. В. Социология юмора. Очерки. М.: РАН, 1996. 214 с.

20. Жан-Поль. Приготовительная школа эстетики. М.: Искусство, 1981. 448 с.

21. Зарецкий В. К., Ковалева Н. Б. Введение в психологию научно-технического творчества. М.: ВГКПИ, 1987. С. 224

22. Кант И. Сочинения: в 6 т. М., 1986. Т. 5. 653 с

23. Карасев Л. В. Философия смеха: монография. М.: РГГУ, 1996. 222 с.

24. Козинцев А. Г. Смех: истоки и функции. СПб. : Наука, 2002. 223. с.

25. Ковалева Н. Б. Исследование субъектности культурных предпочтений студентов первых курсов на основе рефлексивно-позиционного подхода // Вестник Челябинского педагогического университета. Научный журнал. 2016 , № 1. C. 39-45. 


\section{Внутренний мир человека}

26. Ковалева Н. Б. Проектные характеристики понимания художественного текста // Общество: социология, психология, педагогика. № 4, 2016. С. 72

27. Ковалева Н. Б. Рефлексивно-позиционный подход к сценированию продуктивных форм образовательной антропопрактики // Азимут научных исследований: педагогика и психология. 2016. №2. С. 230-234

28. Ковалева Н. Б., Ковалев Ф. А. Инновационное проектирование образовательных технологий. М.: ГАОУ ВО МИОО, 2015.167 с.

29. Ковалев Ф. А. Развитие личностной позиционности средствами медиагерменевтики. Сб. научных трудов межд. научнопрактической конференции. Екатеринбург, ИЦРОН, 2016. С. 213-215.

30. Лавлинский С. П. Диалог читателей в контексте литературного образования. Кемерово, 2002. 200 с.

31. Лихачев, Д. С., Панченко. А. М., Понырко Н. В.. Смех в Древней Руси. Л.: Наука, 1984. 295 с.

32. Лосев. А. Ф. История античной эстетики. Аристотель и поздняя классика. История античной эстетики, том IV. M.: «Искусство», 1975. 443 с.

33. Лук А. Н. Юмор, остроумие, творчество. М. ; Искусство, 1997. 183 с.

34. Муньиз Л. Проблема юмора в образовании // Социологические исследования. 1996. № 11. С. 79-84

35. Мусийчук М. В. Генетические свойства юмора как эффективное средство преодоления кризисных состояний личности // Кризис как иррациональное явление: сб. мат-в межвуз. науч. конф. Магнитогорск, 2002. Вып. 1. С. 35-39

36. Наумова С. В. Феномены вмененного понимания в самосознании современных подростков // Психологические науки. 2016. № 1 C. 6-8.

37. Новикова О. А. Герменевтический подход к пониманию и созданию юмористических текстов. На занятиях по русскому языку в школе и вузе. Дис... к. пед. н. Красногярск. 229с.

38. Рорти Р. Случайность, ирония и солидарность М.: Русское феноменологическое общество, 1996. 282 с.

39. Обухов А. С. Смех и личность // Развитие личности. №3-4. 1998. С. 83-10

40. Пропп В. Я. Проблемы комизма и смеха. Ритуальный смех в фольклоре (по поводу сказки о Несмеяне). М.: Лабиринт, 1999. $288 \mathrm{c.}$

41. В.М. Розин К вопросу о преподавании духовных дисциплин // Педагогика и просвещение. - 2011. - 1. - С. 55 - 60.

42. Рюмина М. Л. Эстетика смеха Смех как виртуальная реальность. 3-е изд. М.: Книжный дом «Либроком», 2010.320 с.

43. Савчук В. В. Медиафилософия. Приступ реальности. СПБ. : Изд-во РХГА, 2013. 338 с.

44. Семенов И. Н. Современные исследования психологии рефлексии: от истории и методологии через экспериментатику к практике // Психология. Журнал ВШЭ. 2013. Т. 10. № 2. С. 3-76.

45. Слободчиков В. И. Со-бытийная образовательная общность -источник развития и субъект образования // Новые ценности образования. 2010. Т. 43 №1. С. 4-13

46. Скороходова Т.Г. Дети и диалог: философия и практика школьного образования Рабиндраната Тагора // Педагогика и просвещение. - 2015. - 4. - С. 394 - 404. DOI: 10.7256/2306-434X.2015.4.17337.

47. Сычев А.А. Смех как социокультурный феномен. Дис. ... д-ра филос. наук. Саранск, 2004. 362 с.

48. Троицкая Т. С., Петухова О. Е.. Врун, фантазёр, мечтатель? Литературное чтение: 2-й класс. Рабочая тетрадь №2. М.: МЦНМО, 2012. $56 \mathrm{c.}$

49. Троицкий С. А. Дмитриева А.В., Сычева А.А. Смех: социо-философский анализ» (М., 2005) // Вече: Журнал русской философии и культуры. 2007. Вып. 18. С. 313-317.

50. Тульчинский Г. JI. О некоторых нормативно-ценностных механизмах культуры: социокультурная природа и факторы смешного // Методология и методы исследования культуры. Л., 1984. С. 72-78.

51. Фишер А. Д. Круг чтения московских подростков // Аpriori. Серия: Гуманитарные науки. 2016. № 1. С. 39

52. И. Фихте И.Г. Факты сознания. Назначение человека. Наукоучение. Мн.: Харвест, М.: АСТ, 2000. 784 с.

53. Хабермас Ю. Моральное сознание и коммуникативное действие / Пер. С нем. Д. В. Скляднева. СПб. : Наука, 2001. 380 с.

54. Чиксентмихайи. М. В поисках потока. Психология включенности в повседневность. М.: Альпина нон-фикшн, 2015. 194 с.

55. Шатин Ю. В. Герменевтика и майевтика как два способа понимания текста // Критика и семиотика. 2001. № 3-4. С. 164-168.

56. Шачин С. В. Коммуникативная теория разума Юргена Хабермаса и ее применение к некоторым психологическим темам // Культурно-историческая психология. 2012. №1. С 34-46.

57. Юмор. БСЭ. М.: Советская энциклопедия, 1969-1978.

58. Янкелевич В. В. Ирония. Прощение: пер. с фр. / Послесл. В. В. Большакова. - М.: Республика, 2004. - 335 с.

59. Kovaleva N. B. Mediagermenevtika as a resource of personality development // Austrian Journal of Humanities and Social Sciences 1-2 2016. P. 68-70.

60. Ziv A. Personality and sense of humor. N. Y:. Springer Publ. Co, 1984. 183 p.

\section{References (transliterated):}

1. Alekseev N. G. Proektirovanie i refleksivnoe myshlenie // Razvitie lichnosti. 2002. № 1. C. 92-115.

2. Akchurina N. N., D’yakonova A. I., i dr. Praktikum po preobrazovaniyu FGOS v obrazovatel'nye programmy nachal'nogo, osnovnogo i polnogo obshchego obrazovaniya. M.: GAOU MIOO, 2015. 348 s.

3. Aristotel'. Ob iskusstve poezii. M., 1983. $184 \mathrm{~s}$.

4. Asmolov A. G. Vyzovy sovremennosti i perspektivy professional'nogo rosta v mire obrazovaniya // Obrazovatel'naya panorama. 2016. № 1 (5). S. 6-8.

5. Bauman Z. Individualizirovannoe obshchestvo. M.: Logos. 2005. $90 \mathrm{~s}$.

6. $\quad$ Bart R. Izbrannye raboty: Semiotika. M.: Progress, 1989. S. 415-418.

7. Bakhtin M. M. Tvorchestvo Fransua Rable i narodnaya kul'tura Srednevekov'ya i Renessansa. M.: Khudozh. lit,1990.543 c.

8. Bakhtin M. M. Estetika slovesnogo tvorchestva. M.: Iskusstvo, 1979. 543 c.

9. Bergson A. Smekh. Per. s fr. M.: Panorama, 2000. 606. s.

10. Bern E. Igry, v kotorye igrayut lyudi. Lyudi, kotorye igrayut v igry. M.: Eksmo, 2010. 560s.

11. Bogin G. I. Obretenie sposobnosti ponimat': vvedenie v germenevtiku. Tver', 2001. $516 \mathrm{c}$. 


\section{Психология и психотехника 4(91) • 2016}

12. Bodriiyar Zh. Simulyakry i simulyatsiya. Tula: Tul'skii poligrafist, 2013. $204 \mathrm{s.}$

13. Borev Yu. B. Komicheskoe i o tom, kak smekh kaznit nesovershenstvo mira, ochishchaet i obnovlyaet cheloveka i utverzhdaet radost' bytiya. M. ; Iskusstvo, 1970. $275 \mathrm{~s}$.

14. Bulin-Sokolova E. I., Obukhov A. S., Semenov A. L. Budushchee pedagogicheskoe obrazovanie. Napravlenie dvizheniya i pervye prakticheskie shagi // Psikhologicheskaya nauka i obrazovanie. 2014. T. 19. № 3. C 207-226.

15. Veraksa N. E., D’yachenko O. M. Elementy karnaval'noi kul'tury v razvitii rebenka-doshkol'nika//Voprosy psikhologii. M., 1994, No2. S. 77-87.

16. Vygotskii L. S. Problema kul'turnogo razvitiya rebenka. // Vestn. MGU. Ser. 14. Psikhologiya. 1991. № 4. S. 5-19.

17. Gegel'. Soch. : v 14 t. : T. 12: Lektsii po estetike, Kn. 1 M., 1938. 494 s.

18. Dzemidok B.. O komicheskom (per. s pol'skogo). M.: Progress, 1974. $223 \mathrm{~s}$.

19. Dmitriev. A. V. Sotsiologiya yumora. Ocherki. M.: RAN, 1996. 214 c.

20. Zhan-Pol'. Prigotovitel'naya shkola estetiki. M.: Iskusstvo, 1981. $448 \mathrm{s.}$

21. Zaretskii V. K., Kovaleva N. B. Vvedenie v psikhologiyu nauchno-tekhnicheskogo tvorchestva. M.: VGKPI, 1987. S. 224.

22. Kant I. Sochineniya: v 6 t. M., 1986. T. 5. $653 \mathrm{~s}$

23. Karasev L. V. Filosofiya smekha: monografiya. M.: RGGU, 1996. $222 \mathrm{s.}$

24. Kozintsev A. G. Smekh: istoki i funktsii. SPb. : Nauka, 2002. 223. s.

25. Kovaleva N. B. Issledovanie sub"ektnosti kul'turnykh predpochtenii studentov pervykh kursov na osnove refleksivnopozitsionnogo podkhoda // Vestnik Chelyabinskogo pedagogicheskogo universiteta. Nauchnyi zhurnal. 2016, № 1. S. 39-45.

26. Kovaleva N. B. Proektnye kharakteristiki ponimaniya khudozhestvennogo teksta // Obshchestvo: sotsiologiya, psikhologiya, pedagogika. № 4, 2016. S. 72

27. Kovaleva N. B. Refleksivno-pozitsionnyi podkhod k stsenirovaniyu produktivnykh form obrazovatel'noi antropopraktiki // Azimut nauchnykh issledovanii: pedagogika i psikhologiya. 2016. №2. S. 230-234

28. Kovaleva N. B., Kovalev F. A. Innovatsionnoe proektirovanie obrazovatel'nykh tekhnologii. M.: GAOU VO MIO0, 2015.167 s.

29. Kovalev F. A. Razvitie lichnostnoi pozitsionnosti sredstvami mediagermenevtiki. Sb. nauchnykh trudov mezhd. nauchnoprakticheskoi konferentsii. Ekaterinburg, ITsRON, 2016. S. 213-215.

30. Lavlinskii S. P. Dialog chitatelei v kontekste literaturnogo obrazovaniya. Kemerovo, 2002. $200 \mathrm{~s}$.

31. Likhachev, D. S., Panchenko. A. M., Ponyrko N. V.. Smekh v Drevnei Rusi. L.: Nauka, 1984. 295 s.

32. Losev. A. F. Istoriya antichnoi estetiki. Aristotel' i pozdnyaya klassika. Istoriya antichnoi estetiki, tom IV. M.: «Iskusstvo», 1975.443 s.

33. Luk A. N. Yumor, ostroumie, tvorchestvo. M. ; Iskusstvo, 1997. $183 \mathrm{~s}$

34. Mun'iz L. Problema yumora v obrazovanii // Sotsiologicheskie issledovaniya. 1996. № 11. S. 79-84

35. Musiichuk M. V. Geneticheskie svoistva yumora kak effektivnoe sredstvo preodoleniya krizisnykh sostoyanii lichnosti // Krizis kak irratsional'noe yavlenie: sb. mat-v mezhvuz. nauch. konf. Magnitogorsk, 2002. Vyp. 1. S. 35-39

36. Naumova S. V. Fenomeny vmenennogo ponimaniya v samosoznanii sovremennykh podrostkov // Psikhologicheskie nauki. 2016. № 1 S. 6-8.

37. Novikova O. A. Germenevticheskii podkhod k ponimaniyu i sozdaniyu yumoristicheskikh tekstov. Na zanyatiyakh po russkomu yazyku v shkole i vuze. Dis... k. ped. n. Krasnogyarsk. 229s.

38. Rorti R. Sluchainost', ironiya i solidarnost' M.: Russkoe fenomenologicheskoe obshchestvo, 1996. $282 \mathrm{~s}$.

39. Obukhov A. S. Smekh i lichnost' // Razvitie lichnosti. №3-4. 1998. S. 83-10

40. Propp V. Ya. Problemy komizma i smekha. Ritual'nyi smekh v fol'klore (po povodu skazki o Nesmeyane). M.: Labirint, 1999.288 s.

41. V.M. Rozin K voprosu o prepodavanii dukhovnykh distsiplin // Pedagogika i prosveshchenie. - 2011. - 1. - C. 55 - 60.

42. Ryumina M. L. Estetika smekha Smekh kak virtual'naya real'nost'. 3-e izd. M.: Knizhnyi dom «Librokom», $2010.320 \mathrm{~s}$.

43. Savchuk V. V. Mediafilosofiya. Pristup real'nosti. SPB. : Izd-vo RKhGA, 2013. $338 \mathrm{s.}$

44. Semenov I. N. Sovremennye issledovaniya psikhologii refleksii: ot istorii i metodologii cherez eksperimentatiku k praktike // Psikhologiya. Zhurnal VShE. 2013. T. 10. № 2. S. 3-76.

45. Slobodchikov V. I. So-bytiinaya obrazovatel'naya obshchnost' -istochnik razvitiya i sub"ekt obrazovaniya // Novye tsennosti obrazovaniya. 2010. T. 43 №1. S. 4-13

46. Skorokhodova T.G. Deti i dialog: filosofiya i praktika shkol'nogo obrazovaniya Rabindranata Tagora // Pedagogika i prosveshchenie. - 2015. - 4. - C. 394 - 404. DOI: 10.7256/2306-434X.2015.4.17337.

47. Sychev A.A. Smekh kak sotsiokul'turnyi fenomen. Dis.... d-ra filos. nauk. Saransk, 2004. 362 c.

48. Troitskaya T. S., Petukhova O. E.. Vrun, fantazer, mechtatel'? Literaturnoe chtenie: 2-i klass. Rabochaya tetrad' №2. M.: MTsNMO, 2012.56s.

49. Troitskii S. A. Dmitrieva A.V., Sycheva A.A. Smekh: sotsio-filosofskii analiz» (M., 2005) // Veche: Zhurnal russkoi filosofii i kul'tury. 2007. Vyp. 18. S. 313-317.

50. Tul'chinskii G. JI. O nekotorykh normativno-tsennostnykh mekhanizmakh kul'tury: sotsiokul'turnaya priroda i faktory smeshnogo // Metodologiya i metody issledovaniya kul'tury. L., 1984. S. 72-78.

51. Fisher A. D. Krug chteniya moskovskikh podrostkov // Apriori. Ceriya: Gumanitarnye nauki. 2016. № 1. S. 39

52. I. Fikhte I.G. Fakty soznaniya. Naznachenie cheloveka. Naukouchenie. Mn.: Kharvest, M.: ACT, 2000. 784 s.

53. Khabermas Yu. Moral'noe soznanie i kommunikativnoe deistvie / Per. S nem. D. V. Sklyadneva. SPb. : Nauka, 2001. 380 s.

54. Chiksentmikhaii. M. V poiskakh potoka. Psikhologiya vklyuchennosti v povsednevnost'. M.: Al'pina non-fikshn, $2015.194 \mathrm{~s}$.

55. Shatin Yu. V. Germenevtika i maievtika kak dva sposoba ponimaniya teksta // Kritika i semiotika. 2001. № 3-4. S. 164-168.

56. Shachin S. V. Kommunikativnaya teoriya razuma Yurgena Khabermasa i ee primenenie k nekotorym psikhologicheskim temam // Kul'turno-istoricheskaya psikhologiya. 2012. №1. S 34-46.

57. Yumor. BSE. M.: Sovetskaya entsiklopediya, 1969-1978.

58. Yankelevich V. V. Ironiya. Proshchenie: per. s fr. / Poslesl. V. V. Bol'shakova. - M.: Respublika, 2004. - 335 s.

59. Kovaleva N. B. Mediagermenevtika as a resource of personality development // Austrian Journal of Humanities and Social Sciences 1-2 2016. P. 68-70.

60. Ziv A. Personality and sense of humor. N. Y:. Springer Publ. Co, 1984. 183 p. 